\title{
Experimental transmission of Caryospora kutzeri (Apicomplexa: Eimeriidae) by rodent hosts
}

\author{
Jiř́i Volf ${ }^{1}$, David Modrý ${ }^{1,2}$ and Břetislav Koudela ${ }^{1,2}$ \\ ${ }^{1}$ Department of Parasitology, University of Veterinary and Pharmaceutical Sciences Brno, Palackého 1-3, 61242 Brno, Czech \\ Republic; \\ ${ }^{2}$ Institute of Parasitology, Academy of Sciences of the Czech Republic, Branišovská 31, 37005 České Budějovice, Czech \\ Republic
}

Key words: Coccidia, Eimeriidae, Caryospora kutzeri, Falco tinnunculus, transmission, paratenic host

\begin{abstract}
Four laboratory-hatched European kestrels Falco tinnunculus L. were fed on laboratory mice and common voles Microtus arvalis Pallas previously inoculated with different doses of sporulated oocysts of Caryospora kutzeri Böer, 1982. Two kestrels that were fed infected mice shed $C$. kutzeri oocysts 6 days after ingesting murine tissues. To compare direct and indirect transmissions, two of the kestrels were subsequently directly inoculated with $10^{5}$ sporulated $C$. kutzeri oocysts and became patent on days 8 and 9 and shed caryosporan oocysts up to day 25 post inoculation. Additionally, four mice were inoculated with $10^{6}$ oocysts in order to examine mouse tissues for the presence of developmental stages of $C$. kutzeri. No coccidian stages were found in the tissues of inoculated mice. The experiment showed that developmental stages of $C$. kutzeri are able to survive in mouse tissues and cause infection of suitable host after their ingestion.
\end{abstract}

The coccidian genus Caryospora Léger, 1904, the third largest genus within the family Eimeriidae represents especially parasites of snakes and raptorial birds. The members of this genus were considered monoxenous up to the early eighties. The experimental study of the life cycle of Caryospora bubonis Stockdale et Cawthorn, 1981 suggested that some caryosporan species possess an indirect life cycle (Stockdale and Cawthorn 1981, Cawthorn and Stockdale 1982). However, the indirect development was well documented in two members of the genus. Up to date, Caryospora bigenetica Wacha et Christiansen, 1982 and Caryospora simplex Léger, 1904, both parasites of viperid snakes, have been found to posses facultatively indirect life cycles, which is unique within the family Eimeriidae. These two coccidians use snakes as primary and mammals as secondary hosts (Wacha and Christiansen 1982a, b, Upton et al. 1984). Nevertheless, descriptions of the indirect life cycle of the avian Caryospora species have not been published because no developmental stages have been found in tissues of mammals experimentally inoculated with oocysts isolated from birds (Stockdale and Cawthorn 1981, Cawthorn and Stockdale 1982, Lindsay et al. 1994). Although, successful experimental transmissions to hosts using previously infected mammals have been reported (Stockdale and Cawthorn 1981, Böer 1982).

Caryospora kutzeri Böer, 1982 infections represent an important health problem of falcons kept in raptor rehabilitation centres as well as of those kept for falconry (Cawthorn 1993, Heidenreich 1997, Pavlík et al. 1998). Therefore the knowledge of transmission routes of this pathogen plays an important role in control and prophylactics of clinical caryosporosis. The aim of the present study is to confirm the indirect life cycle of $C$. kutzeri under controlled experimental conditions.

\section{MATERIALS AND METHODS}

Experimental animals. Sixteen adult outbred coccidiafree CD-1 (ICR) BR mice of both sexes (AnLab s.r.o., Praha) and six subadult coccidia-free common voles Microtus arvalis (Pallas) of both sexes (obtained from the laboratory breeding unit of the Institute of Vertebrate Biology, Academy of Sciences of the Czech Republic, Studenec) were used. Rodents were housed in standard plastic cages with wooden shavings as bedding and were fed on standard rodent diet and water ad libitum. Two severe combined immunodeficient (SCID) mice were maintained in an isolation room under pathogen-free conditions, housed in a cage in flexible film isolators (BEM, Znojmo, Czech Republic) equipped with high-efficiency particulate air (HEPA) filters. All cages, food, water and bedding were sterilised before use. The health state of all rodents was monitored daily.

Four (No. 1-4) laboratory-hatched European kestrels Falco tinnunculus L. were used for experimental inoculation. Eggs of these falcons were obtained from Raptor Rehabilitation Station in Pavlov, Czech Agency for Nature Conservation, Czech Republic. The eggs were incubated artificially and chicks were reared without contact with any other birds. Kestrels were housed individually in cages and fed with oneday-old chicks and with coccidia-free laboratory mice.

Parasite origin and preparation. Caryospora kutzeri oocysts originated from naturally infected saker falcon Falco cherrug Gray from the Raptor Rehabilitation Station in 
Pavlov, Czech Agency for Nature Conservation, Czech Republic. These oocysts were used for experimental inoculation of one European kestrel Falco tinnunculus. Faeces of the experimentally inoculated kestrel containing C. kutzeri oocysts were collected and allowed to sporulate in Petri dishes in a thin layer of $2.5 \%(\mathrm{w} / \mathrm{v})$ potassium dichromate $\left(\mathrm{K}_{2} \mathrm{Cr}_{2} \mathrm{O}_{7}\right)$ solution at laboratory temperature. Sporulated oocysts were purified by flotation in Sheather's sugar solution and stored at $4^{\circ} \mathrm{C}$ for less than one month prior use. Immediately before inoculation, sporulated caryosporan oocysts were washed three times by centrifugation in tap water. The number of oocysts in each inoculum was determined using a haemocytometer.

Experiment 1 (transmission of C. kutzeri to kestrels using previously infected rodents). Summarised schedule of the experiments is shown in Table 1 . Twelve mice and six common voles were orally inoculated with $10^{3}$ sporulated oocysts of $C$. kutzeri and six other mice received $10^{4}$ sporulated oocysts of $C$. kutzeri. Three weeks later, the inoculated rodents were subsequently fed to four 45 -day-old kestrels. Six mice inoculated with $10^{3}$ sporulated oocysts of $C$. kutzeri were fed to kestrel No. 1; similarly, six inoculated common voles were fed to No. 2. Kestrel No. 3 was immunosuppressed by dexamethasone (Dexason, ICN Galenika, Yugoslavia; s.c. 9 $\mathrm{mg} \cdot \mathrm{kg}^{-1} \mathrm{q} .72$ hours) two days before feeding with inoculated mice. Dexamethasone treatment continued during the whole experiment. This kestrel was fed six mice inoculated with $10^{3}$ oocysts. Kestrel No. 4 was fed six mice inoculated with $10^{4}$ oocysts. All kestrels were fed six inoculated rodents during 5 consecutive days. Faecal samples of kestrels were collected daily from the bottom of cages and examined for the presence of oocysts using flotation in Sheather's sugar solution over a period of one month.

To verify the infectivity of inoculum used in the experiment as well as to obtain high number of oocysts for the second experiment, two of four of above used kestrels (No. 1 and 2) were treated with dexamethasone as described previously and two days later inoculated with $10^{5}$ sporulated oocysts of $C$. kutzeri. The treatment continued for a period of 21 days. The faecal samples were collected daily from the bottom of cages up to 25 days post inoculation (DPI) and treated as described above to obtain sporulated oocysts.

Experiment 2 (detection of endogenous stages of $\boldsymbol{C}$. kutzeri in rodents). Four CD1 and two SCID mice were orally inoculated with $10^{6}$ sporulated oocysts of C. kutzeri and euthanised 18 DPI. At necropsy, native smears from peritoneal cells were prepared and observed using Nomarski interference contrast (NIC) microscopy for presence of coccidian developmental stages. Part of the smears were air dried, fixed with methanol and stained with Giemsa for examination using light microscopy. For histological examination, the following tissues were collected from inoculated mice and fixed in $10 \%$ buffered formalin: oesophagus, stomach, duodenum, jejunum, ileum, caecum, rectum, lung, liver, kidney, spleen, mesenteric lymph nodes, tongue, heart, diaphragm, muscles of the abdominal wall, brachial muscles (m. triceps brachii), thigh muscles $(\mathrm{m}$. quadriceps femoris), masseters, upper cheek, eyelid, nose, foot pads, external genitalia and brain. Fixed tissues were processed by standard histological methods. Paraffin sections were stained with haematoxylin and eosin (HE) and examined by light microscopy. Additionally, samples of brachial and thigh muscles, together weighing $5 \mathrm{~g}$, as well as the rest of heart muscle were digested using trypsin digestion method (Rommel et al. 1995) and Giemsa stained smears were examined by light microscopy.

\section{RESULTS}

Experiment 1 (Table 1) demonstrated the indirect transmission of $C$. kutzeri to kestrels by rodents. Two kestrels (Nos. 3 and 4) fed on previously infected mice shed oocysts. Kestrel No. 3 shed few oocysts on day 6 after it was fed the first inoculated mouse. During the following coprological examinations on days 7-25, no oocysts were found. Similarly, kestrel No. 4 shed small numbers of oocysts from day 6 to day 10 after being fed on the first inoculated mouse. No oocysts were found in faecal samples of kestrels No. 1 and 2. No health state alterations were observed in kestrels during the experiment.

Unlike the feeding experiment, examinations of tissue sections and smears of peritoneal macrophages and trypsin-digested muscles of inoculated experimental mice did not reveal the presence of coccidian developmental stages. Neither clinical nor pathological changes were observed in examined immunocompetent and even SCID mice.

Two kestrels (No. 1 and 2) subsequently directly inoculated with $C$. kutzeri oocysts began to shed oocysts 7-8 DPI. Oocysts were detected in the faeces up to the end of the experiment (25 DPI).

\section{DISCUSSION}

Results of the present experiment demonstrated the indirect transmission of Caryospora kutzeri by rodents in two of four kestrels used.

Other authors (Stockdale and Cawthorn 1981, Böer 1982, Cawthorn and Stockdale 1982) also described the indirect transmission of caryosporan coccidia in raptorial birds. In the experiment managed by Cawthorn and Stockdale, three great horned owls Bubo virginianus were used. Each of them was fed on two mice, previously inoculated with sporulated oocysts of Caryospora bubonis. The prepatent period in all three indirectly infected owls was shortened by 48 hours in comparison with direct transmission. In Böer's experimental transmission, a mixture of Caryospora neofalconis and C. kutzeri oocysts was used. Two mice previously inoculated with the oocysts were fed to each experimental kestrel. Only one of three kestrels shed caryosporan oocysts, but only those of $C$. kutzeri. The prepatent period was 10 days versus 8-13 days in cases of direct transmissions.

Handicapped birds from the wild whose health status was unknown were used in previous experimental studies (Stockdale and Cawthorn 1981, Böer 1982, 
Table 1. Summarised schedule of experiment 1.

\begin{tabular}{|c|c|c|c|c|}
\hline $\begin{array}{c}\text { Kestrel } \\
\text { No. }\end{array}$ & $\begin{array}{c}\text { Rodent species } \\
\text { used }\end{array}$ & $\begin{array}{c}\text { Original inoculum } \\
\text { (oocysts per rodent) }\end{array}$ & Immunosuppression & $\begin{array}{c}\text { Oocysts shedding / days post } \\
\text { first rodent was fed }\end{array}$ \\
\hline 1 & mouse & $10^{3}$ & no & no \\
2 & common vole & $10^{3}$ & no & no \\
3 & mouse & $10^{3}$ & yes & yes / 6 \\
4 & mouse & $10^{4}$ & no & yes / 6-10 \\
\hline
\end{tabular}

Cawthorn and Stockdale 1982). The use of laboratoryhatched kestrels for experimental indirect transmission eliminates any possibility of previous Caryospora infection.

Although the shedding of oocysts occurred only in two of four kestrels, it is evident that developmental stages of $C$. kutzeri are able to survive in mouse tissues and cause infection in other suitable hosts after their ingestion. The kestrel fed with mice inoculated with $10^{4}$ oocysts and the kestrel immunosuppressed by corticosteroids shed oocysts of C. kutzeri, in contrast to kestrels fed with rodents receiving 10 times lower infectious dose $\left(10^{3}\right.$ oocysts $)$. Based on these results, it seems likely that the infectious dose, and raptor immunity, both play a role in transmission of caryosporan coccidia by rodent host.

Common voles serve as the most common prey of kestrels in natural conditions and could, therefore, play an important role in the transmission of caryosporan coccidia. We suspect that the low infectious dose accounts for the ineffectual indirect transmission of $C$. kutzeri.

The prepatent period of indirect transmission was shortened by 24-48 hours in comparison with the direct one. This result corresponds well with those of Cawthorn and Stockdale (1982) and Stockdale and Cawthorn (1981) as well as with results of experimental studies of Isospora spp. from dogs and cats which can use paratenic hosts (Dubey 1975, 1978, Frenkel and Dubey 1972, Dubey and Mehlhorn 1978).
The sensitivity of experimental transmission is evidently higher than the sensitivity of direct detection of coccidian stages using histological methods. Regardless of the infectious dose used in experiment 2, caryosporan developmental stages could not be detected in histological sections. In our previous studies on SCID mice was shown that $C$. kutzeri does not undergo multiplication (Koudela et al. 2000). Those results were confirmed in the present experiment using high dose $\left(10^{6}\right)$ of oocysts. This suggests that $C$. kutzeri may be similar to some isosporan coccidia. The tissues of inoculated rodents did not possess any pathological changes. Pathological changes reported by Cawthorn and Stockdale (1982) in mice infected with Caryospora bubonis were tentatively suggested to be a result of infection, but such conclusions without direct demonstration of parasite stages are questionable.

Our results confirmed that $C$. kutzeri is transmissible to falconid hosts by mice previously infected with sporulated oocysts. Therefore it is important to avoid feeding falcons with wild mice and/or other wild mammals which can serve as a source of infection with Caryospora.

Acknowledgements. We thank Zdena Procházková and Veronika Schacherlová for laboratory assistance and Monika Kadlecová for taking care of laboratory animals. We are indebted to the staff of the Raptor Rehabilitation Station in Pavlov, Czech Agency for Nature Conservation, Czech Republic for helpful co-operation and providing kestrel eggs. This study was supported by grant of Ministry of Education, Youth and Sports of the Czech Republic No. 1243/99.

\section{REFERENCES}

BÖER B. 1982: Untersuchungen über das Vorkommen von Kokzidien bei Greifvögeln und über die Entwicklung von zwei Caryospora-Arten der Falken (Caryospora neofalconis n. sp. und Caryospora kutzeri n. sp.). Dissertation, Institut für Parasitologie der Tierärztlichen Hochschule Hannover, 83 pp.

CAWTHORN R.J. 1993: Cyst-forming coccidia of raptors: significant pathogens or not? In: P.T. Redig, J.E. Cooper, J.D. Remple and D.B. Hunter (Eds.), Raptor Biomedicine. University of Minnesota Press, Minneapolis, pp. 14-20.

CAWTHORN R.J., STOCKDALE P.H.G. 1982: The develop- mental cycle of Caryospora bubonis Cawthorn and Stockdale 1981 (Protozoa: Eimeriidae) in the great horned owl, Bubo virginianus (Gmelin). Can. J. Zool. 60: 152157.

DUBEY J.P. 1975: Experimental Isospora canis and Isospora felis infection in mice, cats and dogs. J. Parasitol. 22: 416417.

DUBEY J.P. 1978: Life cycle of Isospora ohionensis in dogs. Parasitology 77: 1-11.

DUBEY J.P., MEHLHORN H. 1978: Extraintestinal stages of Isospora ohionensis from dogs in mice. J. Parasitol. 64: 689-695. 
FRENKEL J.K., DUBEY J.P. 1972: Rodents as vectors for feline coccidia Isospora felis and Isospora rivolta. J. Infect. Dis. 125: 69-72.

HEIDENREICH M. 1997: Birds of Prey, Medicine and Management. Blackwell Science Ltd, Oxford, $284 \mathrm{pp}$.

KOUDELA B., MODRÝ D., VOLF J., ŠLAPETA J.R.: SCID mice as a tool for evaluation of heteroxenous life cycle pattern of Caryospora (Apicomplexa, Eimeriidae) species. Vet. Parasitol. 92: 191-198.

LINDSAY D.S., UPTON S.J., SUNDERMANN C.A., McKOWN R.D., BLAGBURN, B.L. 1994: Caryospora tremula and Sarcocystis sp. from turkey vultures, Catharates aura: description of oocysts and sporocysts and attempted transmission to rodents. J. Helminthol. Soc. Wash. 6: 12-16.

PAVLÍK I., ČERNÍK J., BÁRTA J., PECKA Z. 1998: Occurrence of coccidia (Caryospora neofalconis and Caryospora kutzeri) in birds of prey in falcon breeding facility in Milotice in the Czech Republic. Vet. Med. (Prague) 43: 301-306.
ROMMEL M., TENTER A.M., HORN K., DAUGSCHIES A., MERTENS C., HEYDORN A.O., ENTZEROTH R., ESCHENBACHER K.H., KLEIN H. 1995: Sarcocystis species. In: J. Eckert, R. Braun, M.W. Shirley, and P. Coudert (Eds.), Guidelines on Techniques in Coccidiosis Research. Office for Official Publications of the European Communities, Luxembourg, pp. 241-284.

STOCKDALE P.H.G., CAWTHORN R.J. 1981: The coccidian Caryospora bubonis in the great horned owl (Bubo virginianus). J. Protozool. 28: 255-257.

UPTON S.J., CURRENT W.L., ERNST J.V., BARNARD S.M. 1984: Extraintestinal development of Caryospora simplex (Apicomplexa: Eimeriidae) in experimentally infected mice, Mus musculus. J. Protozool. 31: 392-398.

WACHA R.S., CHRISTIANSEN J.L. 1982a: Development of Caryospora bigenetica $\mathrm{n}$. sp. (Apicomplexa, Eimeriidae) in rattlesnakes and laboratory mice. J. Protozool. 29: 272278.

WACHA R.S., CHRISTIANSEN J.L. 1982b: Life-cycle pattern of Caryospora sp. (Coccidia). J. Protozool. 29 (Abstract 26): 289.

Accepted 3 August 2000 